\title{
A Crossroads for Social Entrepreneurship: Profits versus Ethics
}

\author{
Sandrine Fuentes ${ }^{1}$, Hugo Valenzuela-Garcia ${ }^{2}$ \\ ${ }^{1}$ Department of French Philology and Linguistics, Universitat Autònoma de Barcelona, Barcelona, Spain \\ ${ }^{2}$ Department of Social and Cultural Anthropology, Universitat Autònoma de Barcelona, Barcelona, Spain \\ Email: sandrine.fuentes@uab.cat, hugo.valenzuela@uab.cat
}

How to cite this paper: Fuentes, S. and Valenzuela-Garcia, H. (2019) A Crossroads for Social Entrepreneurship: Profits versus Ethics. Open Journal of Business and Management, 7, 848-860. https://doi.org/10.4236/ojbm.2019.72058

Received: March 20, 2019

Accepted: April 16, 2019

Published: April 19, 2019

Copyright (c) 2019 by author(s) and Scientific Research Publishing Inc. This work is licensed under the Creative Commons Attribution International License (CC BY 4.0).

http://creativecommons.org/licenses/by/4.0/

(c) () Open Access

\begin{abstract}
This paper reveals one of the most critical challenges faced by Spanish social entrepreneurship: either prioritizing ethical, social and environmental objectives or profit-seeking. Social entrepreneurship (those initiatives that pursue social and environmental objectives as well as economic ones) has become a very celebrated sector welcomed by political leaders, international corporations, large financial actors and the public opinion alike. The motto that another economy is possible is gaining momentum while an enormous number and variety of both public and private promotional programs are fostering and energizing such promising sector in practically any spot of the world. However, unlike more conventional enterprises, social entrepreneurship face some crucial challenges due to its own hybrid nature and the goal of making philanthropy (i.e., ensuring the social and environmental values) compatible with profit. A mixed-methods oriented research conducted in Catalonia (Spain) reveals some of these contradictions and challenges. As concluding remarks, we provide some clues to reconsider the scope of social entrepreneurship under a different political economy framework.
\end{abstract}

\section{Keywords}

Social Entrepreneurship, Catalonia, Neoliberal State, Public Intervention

\section{Introduction}

According to Eyal Halamish, co-CEO of the social media firm OurSay, "a social enterprise is actually a failed business (...) once it becomes profitable, it's just a good enterprise" (quoted in [1]). Does this mean that, in order to survive, a social enterprise (SE) must cease to be socially and environmentally focused? This is the paradox we address in this paper, based on a long-term empirical research 
study carried out in Catalonia, Spain, immediately after the economic crisis of 2008. By analyzing this paradox, we will examine and describe the man traits of the field of SE in Catalonia.

Following the common definition, a SE is an initiative that fulfils a social or environmental mission oriented towards market purposes, using innovative solutions and obtaining high impact [2]-[7]. Accordingly, the field of SE is enthusiastically presented as a true revolution within the wider capitalist system, which will overcome the antiquated welfare state [8] and will contribute, through its portentous sharing economy, to creating a double value: both economic and social (Porter \& Kramer, 2011, quoted in [9]). Not surprisingly, this sector is vigorously promoted by public administrations, private institutions, and international business schools alike. The latter, in fact, lead theorizing about this "new" field [4] [6], trying to transfer their savoir faire from the world of commercial activity to the new sector [10] [11] [12].

However, SE is not a completely new field. It actually responds to the traditional third sector of cooperatives, special work centers, solidarity economy, and NGOs [13], which share a long-lasting tradition in the Catalan ad Spanish case. In the 1980s, however, Ashoka coined the new name "social entrepreneurship" to include many of these forms of social economies and the new label only became fully popularized in Spain 30 years later, in the 2010s. Thus, what is the novelty of SE? SE's current revival is due to its undeniable economic potential. It has become a Strategic Action Field (SAF) disputed by the different stakeholders: major financial actors, public administrations, consultants, practitioners, etc. [14]. The potential of SE lies in the fact that it fulfils the gap left by a welfare state in retreat and makes possible the commodification of diverse social commons [15] - co-working strategies, social innovation, civil ideas and responses to real problems, etc. In other words: it creates work (i.e., it alleviates a chronic problem of unemployment), it offers creative solutions to problems that should be taken care of by the state (i.e., public health, protection of vulnerable people, labor insertion of marginalized communities, etc.), and transforms an apparently unattractive sector for the government and the market (social and environmental "problems") into a valuable economic asset.

As a matter of fact, SE is a global sector that keeps growing and promises to revolutionize the relationship between economic benefits and social/environmental impact. This sector responds to an emergent and structural phenomenon, a manifestation of a realignment of capitalism that is altering the world of work, the understanding of the public and common good and the way in which economic value is created and extracted. This global transformation has been well documented in places as diverse as Europe [16], South Africa [17] or Asia [17] [18].

In this paper, we will describe the foundations, particularities, and contradictions of SE in Catalonia. Finally, we will provide an impartial critique of the viability of SE in our contemporary capitalist economy, detailing both problems and what should be retained. 


\section{Methodology}

This paper is based on a funded research project carried out in Catalonia (Spain) between 2013 and 2016. The study adopted a mixed methods strategy and gathered four sets of empirical data, employing different sociological approaches. First, we gathered 43 case studies of managers, partners, and social/environmental entrepreneurs, using both ethnographic observation in different settings (hubs, co-working spaces, companies, business incubators, and training courses) and three types of interviews: interviews about the economic initiative (sector, year of constitution, initial capital, number of partners, annual revenue, etc.), the entrepreneur (sex, age, educational level, previous employment, aims and motivations starting the business, expectations for the next five years, etc.), and information about the entrepreneur's social and support networks (using specific network analysis software). The second type of data consisted of 93 valid responses gathered through an online survey responded to by members of local business associations, networks, and societies. The third source of data consisted of a database with a total of 347 entries of social and environmental Catalan initiatives from which we were able to determine their geographical concentration, main economic sectors, legal forms of ownership, and the average number of workers. All the interviews were carried out with the prior informed consent of the participants (in return, they were given a document with the main characteristics of their social network) and the data that appear in this text have been conveniently anonymized (see [19] for some other details of the methodology employed).

In this paper, we use an analytical and critical approach derived from the description of the empirical data, the qualitative data extracted from the interviews, and the available literature on SE and on the contemporary anthropology and sociology of work. Specifically, in this last respect, we adopt the Foucauldian critique of entrepreneurship as a sophisticated form of bio-power, i.e., and enhanced neoliberal ideology and practice that projects management over society and the self. Michel Foucault conceptualized bio-power as a generalized business projection over the social body and fabric "to turn individual life itself into a kind of permanent and multiple company" [20]. This idea can be also found in many other contemporary sociologists and social analysts [15] [21] [22] [23] [24]. In the same vein, the business logic is projected towards the management of public administration [25], the State [26] [27] [28] [29] or any other institution, encapsulating the principles of neoclassical economics: individualism, opportunism, maximization, competition, etc., which acquire a preponderant role in the way of earning a living [30] and in the expression of subjectivity [31].

\section{Discussion: SE in Catalonia, Spain}

The effect of the 2008 crisis has been devastating, particularly in peripheral Europe: in eastern countries like Slovenia or Ireland and in Mediterranean countries like Portugal, Greece, Italy or Cyprus. In Spain, for example, in the after- 
math of the crisis unemployment exceeded $30 \%$ of the active population; inequality and poverty increased dramatically (with $30 \%$ of the population below the poverty line and $7 \%$ in severe poverty), and the economic sector suffered a massively destruction, mainly affecting small and medium-sized firms which traditionally represent the $99.8 \%$ of the Spanish business fabric [32]. As in other places in Europe, work was not only scarce but precarious as well (temporal, informal, flexible, etc.) [33], thus an important portion of the population was forced to migrate in search of better chances or to reinvent themselves assuming an inevitable socioeconomic downward mobility.

Faced with this adversity, a broad civic movement emerged in different parts of Europe, claiming the imperative to subordinate the economic benefit to the social interest [8] [34] [35]. In this context, worsened by austerity policies, the traditional third sector along with cooperatives and local exchange systems or LETS [36] [37] were reactivated, giving rise to the exchange economy, local barter, time banks, social currencies, etc. Similar forms of solidarity economy alternatives have been documented in many other places in times of crisis or when access to material resources and money was drastically reduced: Venezuela and Cuba for many years, the Argentinian corralito, or the manifold exchange and reciprocal arrangements among Muscovites during the 1980s [38], to mention just a few.

In Spain, like in many other places, these new forms of companies pursuing both market and social objectives were relabeled under the general umbrella of SE. Those that presented a greater economic potential were nevertheless presented as an example of the vitality and potential of the sector; the sector became a Strategic Action Field (SAF) [14], disputed by different stakeholders: banks, financial actors, public companies, consultants, etc. Suddenly, social entrepreneurship became an immense and prosperous industry that represented an opportunity to relaunch, with a top-down strategy, a selection of initiatives-possibly the most profitable-under a new brand: SE, a friendlier alternative to the classic commercial company, with seductive added value (social, ecological, or solidarity) and a great potential to both make the commons profitable and compensate for the deficiencies of a welfare state in retirement.

Most of the social entrepreneurs found in Catalonia could be defined as the creative class, with the peculiarity that they are self-employed. The so-called creative class [39] describes a collective of relatively young, flexible, highly qualified, and cosmopolitan people whose work implies some type of intensive creation and innovation, such as technologists, scientists, engineers, professors, architects, health workers, consultants, or artists. Currently, this sector probably exceeds the $30 \%$ of the active population in the United States and the United Kingdom [40] and 10\% in Spain [25]. In general, this group shares what Ronald Inglehart called "post-materialist motivations": incentives beyond salary or wealth, such as self-fulfillment, social improvements, and environmental sustainability [41] [42]. According to our sample, $60 \%$ of social entrepreneurs are male, their average age is 42 years, and most of them are highly educated: $80 \%$ 
hold a university degree and, of these, $20 \%$ hold a Master's degree or PhD. These entrepreneurs declare a social and ecological motivation (48.9\%) as the main reason for starting the firm, followed by personal fulfilment (31.1\%) and, only in third place, an economic incentive. Nonetheless, $47 \%$ worked for third parties $(28.6 \%$ salaried employees and $18 \%$ as directors or managers), $14.3 \%$ were self-employed, and $10 \%$ were unemployed immediately before starting the initiative.

Most of the firms (60\%) were established after 2008, immediately after the crisis. In general, these are family businesses located in urban or peri-urban areas run by few owners and with a discrete turnover (average of $€ 100,000$ per year), $80 \%$ of which is derived from commercial activities. However, it is important to note that this is a highly subsidized sector: $48 \%$ of the initiatives have had some kind of private or public subsidy; donations (20\%), micro-financing (10.5\%) or external investments (17.4\%); and only $9.6 \%$ have resorted to bank loans. With an average of 14 workers per company, we also noted an important presence of volunteers, apprentices, and trainees. The most common legal form is the cooperative (56.5\%) because of greater tax exemptions, followed by the limited company (19\%).

There are three main sectors operating under the SE label at different scales: environmental and ecological initiatives (19\%), a heterogeneous commercially oriented collection of firms (20\%), and services (61\%).

The environmental and ecological sector (roughly 19\%) is heterogeneous, including a great range of small-scale initiatives aimed at vegetables, wheat flour, and fruit production, usually led by qualified middle-aged professionals (agronomists, ecologists, biologists, or geographers) who were previously unemployed or either opted for an alternative livelihood. Most of the facilities (mills, cold chambers, ovens, etc.) are financed by their own means or by family savings, small loans, crowdfunding, or cooperative credit. Their level of indebtedness varies a lot: from family businesses that opted for high-risk loans to more humble initiatives launched with a few thousand euros. Beyond these small-scale family firms, we also include the traditional Catalan cooperative sector [43], which has been historically an effective alternative to fighting against structural unemployment [44]. Here, we find large cooperatives involved in the production and distribution of organic foods, high-tech engineering, and labor insertion cooperatives usually regarded as the paradigm of SE, because they offer high quality ecological products and employ manpower usually excluded from the ordinary labor market-people with disabilities, former drug-addicts, etc.

Second, we found an assorted commercial sector (roughly 20\%) dedicated to sales and services with an added socio-environmental message or value. Entrepreneurship in this case is clearly a self-employment option. For example, we discovered the case of Talk, a marketing company created by a former commercial employee who, after losing his job in a large telephone company, created his own venture: "I have a gift with communication and I had to do something." In a similar vein, we found many small projects created by individuals who tried to make a living through a particular personal skill, ability, or interest. 
Finally, we discerned a service sector (almost 70\%) which included ethical banking (5\%), caring and social services (health, education, etc.), professional services (communication, design, recycling, etc.) and, above all, consulting. Consulting, as Fleming notes, is a strong industry within the SE sector [15], and operates as a myriad of lucrative services: rental of co-working spaces; organization of workshops, seminars, and training courses; marketing and consulting; event promotion; and substantial agreements with public administrations, private banks, and business schools. Most of these social consultancies emerged as a response to the economic crisis, the restructuration of the consulting sector, and the drastic reduction of these people's client portfolios due to public cuts. According the CEO of Social Consultancy: "The social is a promising market niche, but there is not enough awareness yet."

The cases of Dual and SmartSE are illustrative here. Both consultancies were founded by partners who lost their previous jobs in the sector; they already had a wide portfolio of projects, clients, and networks. Their initial investments in their new companies were relatively low ( $€ 3000$ per partner, because there was no major investment in means of production or infrastructure) and their main source of income was the organization of workshops, seminars, or training courses run by public administrations, banks, and business university departments. These courses did not differ much from the training courses offered by the business schools: "Even if we are a social company, with social objectives, the way to manage it is exactly the same as how a normal company is managed", affirmed one of the partners of Dual. In fact, as observed in situ, in their training management, techniques which are the same as those used in business schools were used and they often underlined the need for projects which were "less social and more viable".

Such courses were usually preceded by presentations led by directors of entrepreneurship programs, representatives of the public administration, successful entrepreneurs, and business school teachers. One public representative highlighted the need for "entrepreneurs to identify needs, take risks, generate results, and know how to efficiently manage the available resources". That may well be a proper definition of entrepreneur in the purest Schumpeterian style. Along with the active (almost proselytized) promotion of SEs, a wide range of hubs, co-working spaces, business incubators, seed spaces and business labs have flourished, defined as "talent activity centers for social change" (according to one successful SE who shared his experience with the audience).

While many of the social entrepreneurs are openly critical of the orthodox way of doing business, almost all these initiatives face the same dilemma: profitability and sustainability. Indeed, after years of struggling, most of them consider the possibility of embracing a more orthodox method of management and marketing, leaving aside (at least momentarily) their social or environmental goal. When interviewed, the founder of a successful SE affirmed he was considering legally transforming the cooperative into a business patronage because "it 
is better that there be a small nucleus of people taking decisions". Another SE remarked that "the economic strategy has to change in order for the company to be profitable".

Although most interviewees praised their work, self-exploitation and precariousness are common. Most amateur social entrepreneurs barely attain a minimum wage and are forced to resort to part-time jobs to make a living. Undeclared payments are common and work pressure frequently impacts negatively on family and personal relationships [45]. Thus, many social entrepreneurs are ready to switch to other work alternatives when available.

\section{Discussion: Paradoxes of SE and Political Economy}

We would like to think that an SE is, generally speaking, a better option than a traditional for-profit company, because the former seeks social or environmental outcomes without forsaking profitability. Yet, according to our analysis, SE cannot escape from several contradictions that may seriously undermine the concept's very possibility. Although a more extensive and comparative case study is required, the Catalan case invites a wider reflection due to the fact, as we mentioned above, that $\mathrm{SE}$ is not a local but a global phenomenon documented worldwide. Next, we will summarize the main contradictions of SE and we will finally make some suggestions.

\subsection{An unclear Definition and a (Subtle) Selection}

First, as we have noted elsewhere [14], the definition of SE is more prescriptive (what it should be) than descriptive (what it actually is). This is so because the institutional definition of SE responds to a sustained flow of ideas and premises from above to below [46]. In other words, it is a sector appropriated and leaded by financial and public actors based on a reconfigured and potentially profitable third sector in times of economic hardship. Consequently, not all initiatives of the third sector are included within the definition of a social enterprise, however, only those options that are more profitable and present a better market profile: companies that employ minority and vulnerable sectors of the population, that create an innovative product with and added value (better if it is ecological, healthy or respectful with the environment) and great potential demand.

Further, because of the hybrid nature of SE (i.e., a blended form of commercial enterprise and third sector), some authors consider the definition also tautological or ambiguous [16] [47] [48] [49]. Indeed, while the economic performance of a firm is relatively simple to assess (income level, profitability, sales, capitalization, growth, number of workers, etc.) the evaluation of the social impact is puzzling and problematic to measure [48] [50] [51]. How can a given social impact be defined in an objective way? In what respect? For whom and to what extent? What unanticipated side-effects could this positive impact have on other groups? How can the impact in both quantitative and qualitative terms be evaluated? All these questions are complex and difficult to answer, as any social 
scientist knows.

\subsection{Profitability versus Ethical Goals}

As we have shown, sustainable profitability seems to be the main weakness of most SEs. As a matter of fact, SEs find more obstacles accessing bank credits than any other commercial enterprise type [52] and, although ethical banking partly covers this gap, the adoption of social performance measurement practices mirrors the increasing rationalization of this sector [49]. In other words, SEs are forced to adopt the same resources and strategies as commercial companies [10] [11]. The training led by business schools and successful entrepreneurs is the main vehicle to inoculate the profit-seeking and rationality criteria typical of the commercial sector. Faced with all these obstacles, and after years of desperate struggle to survive, many social entrepreneurs consider sooner or later transforming their initiative into a commercial firm, therefore betraying the objectives and essence of the SE [25].

Some authors affirm that the very goal of a SE is to achieve a "more ethical and socially inclusive capitalism" [53]. Reading ethics and capitalism in the same sentence may sound like an oxymoron. On the one hand, economic scarcity, self-exploitation, precariousness, and the black economy are not exceptional in the sector. On the other hand, because production costs are high, the final price is high and the final depositories of organic products and social services are those with high purchasing power; this excludes other potential consumers with fewer economic resources. Therefore, an unwanted side effect is that a part of SE production tends to reproduce inequality.

As we have shown, most SEs find it difficult to attain a sustained compromise between profit and the common good. It would seem that the more social the initiative, the less profitable and sustainable it becomes. This holds true in the strict capitalist economy, because neoliberal principles are not easily compatible with altruism [34] [54].

We would argue that, against Milton Friedman's statement, capitalist free market is not always the solution. The solution for SE can be neither strict sustainability nor profitability, because those engender contradiction with social and environmental outcomes. Social entrepreneurs, isolated and pressured by both a neoliberal state [28] that outsources basic welfare responsibilities (e.g., creation of labor or providing social care for vulnerable people) and the pervasive ideology of modern entrepreneurship, cannot attain their objectives by themselves - they need help. A perfect balance between social outcomes, satisfactory revenues, and human dignity cannot be left to interested actors (banking sector, business schools, private foundations, etc.) nor be naturally achieved by the market's invisible hand. Market pressures are very high and socio-environmental outcomes are never enough in our increasingly unequal world. SE should be rethought as a common good, a model for the revolutionary modification of the relationship between economy and society, a fundamental vehicle to provide a 
global solution for work scarcity, social inclusion, and first-order environmental challenges. Thus, for SE to really work political economy should be reconsidered and public intervention should play a central and autonomous role, divorced from market interests if that is still possible.

\section{Conclusions}

This paper has described the fundamental features of social entrepreneurship in Catalonia, Spain. The research used a mixed methods approach (qualitative and quantitative) and a critical perspective based on the current sociology of work and entrepreneurship.

Since the economic crisis of 2008, the field of social entrepreneurship has experienced a considerable boom, encouraged by both public and private initiatives because it presents obvious potentialities: it contributes, through its portentous sharing economy, to create a double value (economic and social); it creates work, it solves problems of social and environmental order and it promotes the ideology of entrepreneurship and individualism (i.e., do-it-yourself).

However, SE is not a new sector, but a new label to group the traditional third sector of cooperatives, special work centers, solidarity economy and NGOs under a same umbrella. The novelty is that today SE, by its undeniable economic potential, has become a Strategic Action Field (SAF) disputed by the different agents at stake: major financial actors, public administrations, consultants, practitioners, etc. As in other parts of the world, the SE is basically formed by self-employed creative class: a collective of relatively young, flexible, highly qualified, and cosmopolitan people which work implies some type of intensive creation and innovation. Most (60\%) of the social entrepreneurs are male, their average age is 42 years and most of them are highly educated: $80 \%$ held a university degree, and of these $20 \%$ a MA or PhD. These entrepreneurs manifest a social and ecological motivation (48.9\%) as the main reason to start the firm, followed by personal fulfilment (31.1\%) and economic incentive. SE sector entails environmental and ecological initiatives (19\%), a heterogeneous commercial-oriented collection of firms (20\%), and services (61\%).

Our research shows that SE cannot escape from several contradictions that may seriously undermine its very possibility. First, the definition of SE is more prescriptive (what it should be) than descriptive (what it actually is) and ambiguous or tautological, since social impact measurement remains puzzling and undefined. Second, and more importantly, the tension between profitability and environmental/social aims seems to dissolve the very idea of social entrepreneurship, since many SE are forced to turn into a commercial firm in order to survive because market and neoliberal principles are not easily compatible with altruism. The balance between social outcomes and revenues cannot be left to interested actors nor market's vagaries, it needs public supervision and a different political economy background-one more centered on the social commons than on the individual gain. 


\section{Acknowledgements}

We thank Dr. José Luis Molina for his unconditional support and great generosity as the leader of the project in which this paper is based: ENCLAVE. Social entrepreneurship: local embeddedness, social networking sites and theoretical development (2013-2015). MINECO (CSO2012-32635). A broader, and more critical and ambitious, version of this text is under revision and it will be published presently in the Spanish journal Revista de Antropología Social: http://revistas.ucm.es/index.php/RASO.

\section{Conflicts of Interest}

The authors declare no conflicts of interest regarding the publication of this paper.

\section{References}

[1] Cara, W. (2017) The Lives and Lies of Social Entrepreneurs. The Sydney Morning Herald.

https://www.smh.com.au/business/small-business/the-lifes-and-lies-of-social-entre preneurs-20170210-guaghc.html

[2] Dacin, P.A., Dacin, M.T. and Matear, M. (2010) Social Entrepreneurship: Why We Don't Need a New Theory and How We Move Forward From Here. The Academy of Management Perspectives, 24, 37-57.

[3] Dees, J.G. (1998) The Meaning of "Social Entrepreneurship". The Kauffman Center for Entrepreneurial Leadership. Kansas City, MO and Palo Alto, CA.

[4] Dees, J.G. (2007) Taking Social Entrepreneurship Seriously. Society, 4, 24-31. https://doi.org/10.1007/BF02819936

[5] Mair, J. (2010) Social Entrepreneurship: Taking Stock and Looking Ahead. In: Fayolle, A. and Matlay, H., Eds., Handbook of Research on Social Entrepreneurship, Edward Elgar, Cheltenham, 20-32. https://doi.org/10.4337/9781849804684.00007

[6] Seelos, C. and Mair, J. (2005) Social Entrepreneurship: Creating New Business Models to Serve the Poor. Business Horizons, 48, 241-246. https://doi.org/10.1016/j.bushor.2004.11.006

[7] Zahra, S.A., Gedajlovic, E., Neubaum, D.O. and Shulman J.M. (2009) A Typology of Social Entrepreneurs: Motives, Search Processes and Ethical Challenges. Journal of Business Venturing, 24, 519-532. https://doi.org/10.1016/j.jbusvent.2008.04.007

[8] Mason, P. (2015) Postcapitalism: A Guide to Our Future. Penguin, UK.

[9] Driver, M. (2012) An Interview with Michael Porter: Social Entrepreneurship and the Transformation of Capitalism. Academy of Management Learning \& Education, 11, 421-431. https://doi.org/10.5465/amle.2011.0002a

[10] Austin, J., Stevenson H. and Wei-Skillern J. (2006) Social and Commercial Entrepreneurship: Same, Different, or Both? Entrepreneurship. Theory and Practice, 30, 1-22. https://doi.org/10.1111/j.1540-6520.2006.00107.x

[11] Meyskens, M., Robb-Post, C., Stamp, J.A., Carsrud, A.L. and Reynolds, P.D. (2010) Social Ventures from a Resource-Based Perspective: An Exploratory Study Assessing Global Ashoka Fellows. Entrepreneurship: Theory and Practice, 34, 661-680. https://doi.org/10.1111/j.1540-6520.2010.00389.x

[12] Corner, P.D. and Ho, M. (2010) How Opportunities Develop in Social Entrepre- 
neurship. Entrepreneurship: Theory and Practice, 34, 635-659.

https://doi.org/10.1111/j.1540-6520.2010.00382.x

[13] Moulaert, F. and Ailenei, O. (2005) Social Economy, Third Sector and Solidarity Relations: A Conceptual Synthesis from History to Present. Urban Studies, 42, 2037-2054. https://doi.org/10.1080/00420980500279794

[14] Molina, J.L., Valenzuela-Garcia, H., Lubbers, M., Escribano, P. and Lobato, M., (2018) The Cowl Does Make The Monk: Understanding the Emergence of Social Entrepreneurship in Times of Downturn. International Journal of Voluntary and Nonprofit Organizations, 29, 725-739. https://doi.org/10.1007/s11266-017-9921-6

[15] Fleming, P. (2014) Resisting Work. The Cooperatization of Life and Its Discontents. Temple University Press, Philadelphia.

[16] Doherty, B., Haugh, H. and Lyon, F. (2014) Social Enterprises as Hybrid Organizations: A Review and Research Agenda. International Journal of Management Reviews, 16, 417-436. https://doi.org/10.1111/ijmr.12028

[17] Moon, C.W. and You Sang, K. (2015) Compassion, Pro-Social motivation, and Social Entrepreneurship: An Empirical Investigation. 3rd Asia-Pacific Conference on Global Business, Economics, Finance and Banking, Singapore, 17-19 July 2015.

[18] Permana, A. and Mursitama, T.N. (2018) The Influence of Ideological Entrepreneurship to Social Enterprise's Succes. Earth and Environmental Science, 126, Article ID: 012105.

[19] Valenzuela-Garcia, H., Lubbers M.J. and Molina, J.L. (2018) Off the Methodological Records: Sample Selection, Institutional Access, and Ambivalent Audit/Ethical Issues When Investigating Vulnerable People. SAGE Research Methods Cases Part 2, UK.

[20] Michel, F. (2008) The Birth of Biopolitics. Lectures at the Collège de France, 1978-1979. Palgrave, London, 241.

[21] Cristina, M. (2007) The Feminization of Labour in Cognitive Capitalism. Feminist Review, 87, 40-59. https://doi.org/10.1057/palgrave.fr.9400367

[22] Tiziana, T. (2000) Free Labor: Producing Culture for the Digital Economy. Social Text, 63, 33-58.

[23] Richard, S. (2002) Living in the Corporate Zoo. Life and Work in 2010. Capostone Publishing Limited, UK.

[24] Anders, K. and Ehrsten, M. (2005) A Theory of Homo Entreprenaurus. In: Vinig, G.T. and Van Der Voort, R.C.W., Eds., The Emergence of Entrepreneurial Economics, Vol. 9, Emerald Group Publishing Limited, London, 211-232. https://doi.org/10.1016/S0737-1071(05)09012-8

[25] Ruiz-Herrero, J.A. (2015) Capitalismo cognitivo: Sus nuevos espacios, técnicas de control y producción, y sus clases profesionales: Dos estudios de caso. PhD Thesis, Departamento de Sociología, Universidad Complutense Madrid.

[26] Michael y Antonio Negri, H. (2000) Empire. Cambridge, Massachusetts. Harvard University Press, London.

[27] Gill, R. and Pratt, A.C. (2008) In the Social Factory? Immaterial Labour, Precariousness and Cultural Work. Theory, Culture \& Society, 25, 1-30. https://doi.org/10.1177/0263276408097794

[28] Wacquant, L. (2009) Punishing the Poor: The Neoliberal Government of Social Insecurity. Duke University Press, London. https://doi.org/10.1215/9780822392255

[29] Mathieu, H. (2012) The Historicity of the Neoliberal State. Social Anthropology, 20, 80-94. https://doi.org/10.1111/j.1469-8676.2011.00192.x 
[30] Carla, F. (2007) The "Reputation" of Neoliberalism. American Ethnologist, 34, 252-267. https://doi.org/10.1525/ae.2007.34.2.252

[31] Richard, S. (1992) The Fall of Public Man. Norton and Company, New York.

[32] Ana, R. (2013) España supera por primera vez los seis millones de parados. El diario.es. http://www.eldiario.es/economia/Espana-supera-millones-parados_0_125637494.html

[33] Mount, I. (2014) España vive "boom” de trabajo informal. CNN Expansión. https://expansion.mx/economia/2014/02/14/economia-informal-de-espana-en-auge

[34] Hart, K. (2015) Economy for and Against Democracy. Vol. 2, the Human Economy, Berghahn.

[35] Phillips, W., Lee, H., Ghobadian, A., O’Regan, N. and James, P. (2015) Social Innovation and Social Entrepreneurship. Group \& Organization Management, 40, 428-461. https://doi.org/10.1177/1059601114560063

[36] Linton, M. (1994) The LETS System Design Manual. Landsman Community Services Paper 1.3 Version 1.3.

[37] Lang, P. (1994) LETS Work: Rebuilding the Local Economy. Grover Books, Bristol.

[38] Caldwell, M.L. (2004) Not Be Bread Alone. Social Support in the New Russia. University of California Press, New York.

[39] Florida, R. (2002) The Rise of the Creative Class: And How It's Transforming Work, Leisure, Community and Everyday Life. Perseus Book Group, New York.

[40] Clifton, N. (2008) The "Creative Class" in the UK: An Initial Analysis. Geografiska Annaler B, 90, 63-82. https://doi.org/10.1111/j.1468-0467.2008.00276.x

[41] Inglehart, R. (1977) The Silent Revolution. Princeton University Press, Princeton.

[42] Inglehart, R. (1989) Culture Shift. Advanced Industrial Society, Princeton University Press, Princeton.

[43] Reventós, J. (1960) El movimiento cooperativo en España. Ariel, Barcelona.

[44] Díaz-Bretones, F. (2000) Desempleo y cooperativismo. CIRIEC-España. Revista de Economía Pública, Social y Cooperativa, 35, 161-176.

[45] Valenzuela, H., Cruces, R.L., et al. (2015) My Job is my Life. Overlap between Life and Work in Spanish Companies. Revista Española de Investigaciones Sociológicas, 150, 191-210.

[46] Hervieux, C., Gedajlovic, E. and Turcotte, M.-F.B. (2010) The Legitimization of Social Entrepreneurship. Journal of Enterprising Communities. People and Places in the Global Economy, 4, 37-67. https://doi.org/10.1108/17506201011029500

[47] Santos, F.M. (2012) A Positive Theory of Social Entrepreneurship. Journal of Business Ethics, 111, 335-351. https://doi.org/10.1007/s10551-012-1413-4

[48] Young, D.R. and Lecy, J. D. (2014) Defining the Universe of Social Enterprise: Competing Metaphors. International Journal of Voluntary and Nonprofit Organizations, 25, 1307-1332. https://doi.org/10.1007/s11266-013-9396-Z

[49] Lall, S. (2017) Measuring to Improve versus Measuring to Prove: Understanding the Adoption of Social Performance Measurement Practices in Nascent Social Enterprises. International Journal of Voluntary and Nonprofit Organizations, 28, 26332657. https://doi.org/10.1007/s11266-017-9898-1

[50] Sud, M., Vansandt C.V. and Baugous, A.M. (2008) Social Entrepreneurship: The Role of Institutions. Journal of Business Ethics, 85, 201-216. https://doi.org/10.1007/s10551-008-9939-1

[51] Manetti, G. (2012) The Role of Blended Value Accounting in the Evaluation of So- 
cio-Economic Impact of Social Enterprises. International Journal of Voluntary and Nonprofit Organizations, 25, 443-464.

https://doi.org/10.1007/s11266-012-9346-1

[52] Arvidson, M. and Lyon, F. (2014) Social Impact Measurement and Non-Profit Organisations: Compliance, Resistance, and Promotion. International Journal of Voluntary and Nonprofit Organizations, 25, 869-886.

https://doi.org/10.1007/s11266-013-9373-6

[53] Dacin, M.T., Dacin, P.A. and Tracey, P. (2011) Social Entrepreneurship: A Critique and Future Direction. Organization Science, 22, 1203-1213. https://doi.org/10.1287/orsc. 1100.0620

[54] Carrier, J.G. (2018) Economy, Crime and Wrong in a Neoliberal Era. Berghahn, New York 